by François-Xavier Devuyst ${ }^{1}$, Luc Hance ${ }^{2}$, Hongfei Hou ${ }^{3}$, Xianghe Wu $^{4}$, Shugang Tian ${ }^{3}$, Michel Coen ${ }^{1}$, and George Sevastopulo ${ }^{5}$

\title{
A proposed Global Stratotype Section and Point for the base of the Viséan Stage (Carboniferous): the Pengchong section, Guangxi, South China
}

\author{
1 Unité de Géologie, Université Catholique de Louvain, 3 Place Louis Pasteur, 1348, Louvain-la-Neuve, Belgium. \\ Email: devuyst@hotmail.com; coen@geol.ucl.ac.be \\ 2 Carmeuse Coordination Center, 65 Boulevard de Lauzelle, 1348, Louvain-la-Neuve, Belgium. Email: luc.hance@skynet.be \\ 3 Institute of Geology, C.A.G.S., 26 Baiwanzhuang Road, Beijing 100037, China. Email:hhongfei@ hotmail.com \\ 4 Guizhou Bureau of Land and Mineral Resources, Beijing Road, Guiyang, China. \\ 5 Department of Geology, Trinity College, Dublin 2, Ireland. Email: gsvstpul@tcd.ie
}

The first appearance of Eoparastaffella simplex in the lineage Eoparastaffella ovalis - Eoparastaffella simplex (foraminifers) has been officially approved by the Voting Members of the SCCS in early 2002 as the new biostratigraphic criterion to define the base of the Viséan. The present paper summarizes eight years of research and proposes a new Global Stratotype Section and Point from Guangxi, South China. The boundary is defined at the base of bed 85 of the Pengchong section where the first E. simplex is recorded, following more primitive Eoparastaffella. The conodont Gnathodus homopunctatus, whose cryptic first appearance has been used as an empirical toolfor identification of the $T-V$ boundary in Western Europe, enters a decimetre higher in bed 86. Scaliognathus anchoralis europensis and other conodonts considered characteristic of the late Tournaisian occur below these levels.

\section{Introduction}

The base of the Viséan is one of the three potential biostratigraphic horizons for the refinement of global intra-Mississippian (Lower Carboniferous) correlations (Brenckle and Manger, 1991). The Working Group on the Tournaisian-Viséan boundary of the Subcommission on Carboniferous Stratigraphy (SCCS) under the chairmanship of George Sevastopulo (Trinity College Dublin) has been active since 1995. Field work has been conducted in Belgium, Ireland, Poland, Iran and China with the aim of defining a new biostratigraphic criterion for the base of the Viséan and of finding a candidate GSSP. Three pontential levels for the base of the Viséan were discussed at the biennial SCCS meeting in Liège (Sevastopulo, 1993). They were: (1) to retain the existing boundary defined in Belgium, which coincides with the cryptic appearance of the foraminifer Eoparastaffella; (2) to seek a boundary coincident with the appearance of the conodont Scaliognathus anchoralis within the lineage $S$. praeanchoralis - S. anchoralis; and (3) to recognize the boundary on ance of the first Eoparastaffella species with an outer subangular periphery (morphotype 2) succeeding species characterized by a rounded periphery (morphotype 1). Species that first appear in basal Viséan strata in the Dinant Basin (Southern Belgium) belong to morphotype 2. Hence, adoption of the proposal of Hance and Muchez (1995) would not significantly change the chronostratigraphic position of the historical boundary but would necessitate finding a new stratotype because morphotype 1 does not occur in the existing Bastion stratotype in the Dinant Basin (see below). This biostratigraphic criterion has been refined subsequently (Hance, 1997; Devuyst et al., 2001; Sevastopulo et al., 2002) and officially approved by a ballot of the Voting Members of the SCCS (Work, 2002). The GSSP candidate proposed in this paper is the Pengchong section (Guangxi, South China) (Figure 1). This section is representative of a basinal setting and, in contrast to other sections considered by the Working Group, records continuous sedimentation across the TournaisianViséan (T-V) boundary. It has yielded significant conodont faunas and rich and diversified foraminifer faunas. In particular, the evolutionary lineage of the genus Eoparastaffella has been very well documented. Although the Pengchong section contains few macrofossils, it has proved possible to correlate (on the basis of foraminifers and conodonts) the base of the Viséan to other nearby sections representing platform-Huaqiao Farm, and slope-Yajiao settings (Figures 1,2) where goniatites, trilobites and corals have been found.

\section{A brief history of the evolution of the terms Tournaisian and Viséan}

The first division of the Carboniferous limestone of Belgium was made by Dumont (1856). Gosselet (1860) first established the succession of an «Etage du Calcaire de Tournai» and an «Etage du Calcaire de Visé» in the Hainaut area, the names refer to the cities of Tournai in western Belgium and Visé in eastern Belgium, at the border with the Netherlands. Dupont (1861) recognized the same succession in the Dinant area where it is more complete and, in 1883, introduced the Tournaisian and Viséan Stages.

A first step toward more rigorously defined stratigraphic subdivisions was achieved more than one century later with the formal 

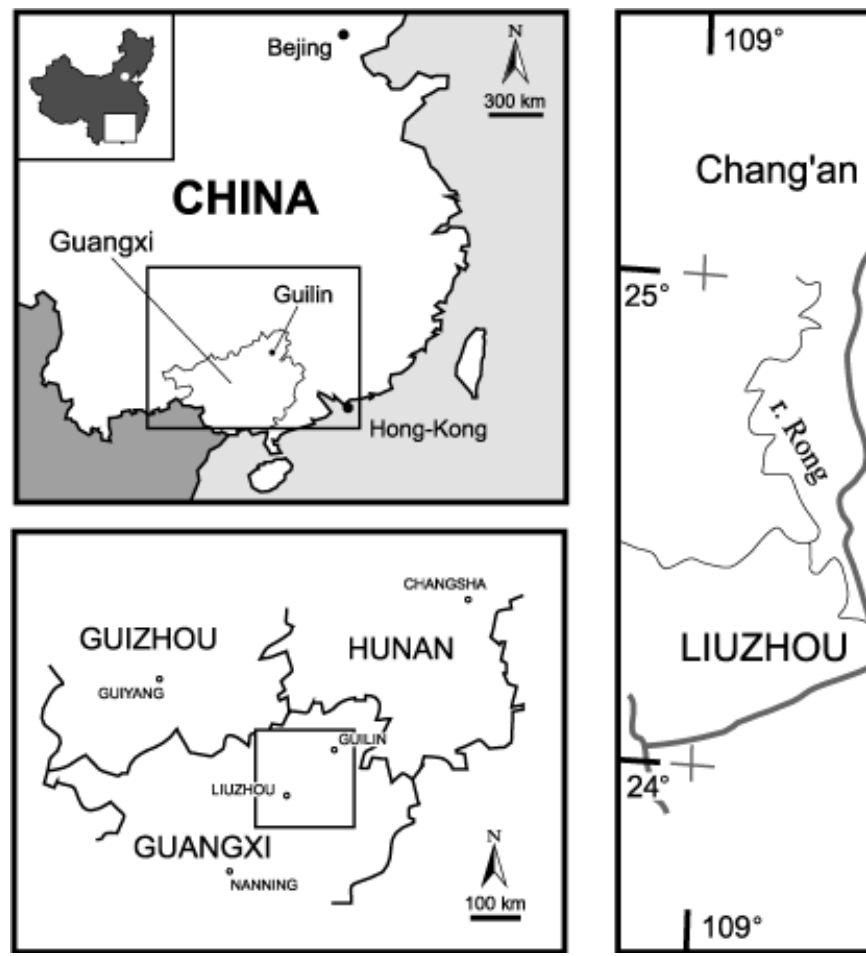

limestone) at the Bastion Section near Dinant, Belgium (SCCS, 1969; George and Wagner, 1969). This level coincides in this section with the first occurrence of the calcareous foraminiferal genus Eoparastaffella (Conil et al., 1969). The first occurrence of the conodont Gnathodus homopunctatus is less than $1 \mathrm{~m}$ above the boundary (Groessens and Noël, 1977).

However, in hind sight, it is clear that the Dinant region was not a good area in which to define the base of the Viséan. During the time spanning the latest Tournaisian and the early Viséan the area was occupied by a residual restricted basin limited to the North by the prograding platform and to the south by the Waulsortian complex. Both the basinal sediments and the micritic peri-waulsortian deposits (exposed in the Bastion section) are characterized by a depauperate association of foraminifers. The Upper Tournaisian Cf3 Tetrataxis-Eotextularia Zone of Conil et al. (1977) reflects this situation and is of limited use for correlation with more open marine facies. All the subsequent entries of uppermost Tournaisian or Viséan taxa are cryptic and occur in thin tempestites derived from shallower areas (Lees, 1997). Notably this is the case with Eoparastaffella, whose most primitive species are not found in the Dinant area. Therefore the Bastion section is not a suitable stratotype. The need for a better definition of the base of the Viséan was well understood by Conil since 1987, after discovery of «Viséan-

\section{The use of Eoparastaffella (foraminifer) to define the base of the Viséan}

Eoparastaffella has been used as an index fossil for the base of the Viséan in various zonal schemes (Brazhnikova and Vdovenko, 1971; Lipina, 1973) since Conil et al. (1969) indicated the coincidence between the entry of this taxon and the base of the Stage in the Bastion stratotype. However the use of unspecified Eoparastaffella for defining the base of the Viséan is unsatisfactory as the most primitive representatives of the genus (E. rotunda, E. ovalis, E. fundata) appear in the Upper Tournaisian $\left(\mathrm{C}_{1} \mathrm{Va}\right.$ of Vdovenko, 1964; Hance, 1997; Ondrackova, 2001; Sevastopulo et al., 2002). The systematics of the genus Eoparastaffella, including its type species simplex, is confused and is currently under revision. Research directed towards a more objective taxonomy of Eoparastaffella has shown that refer-

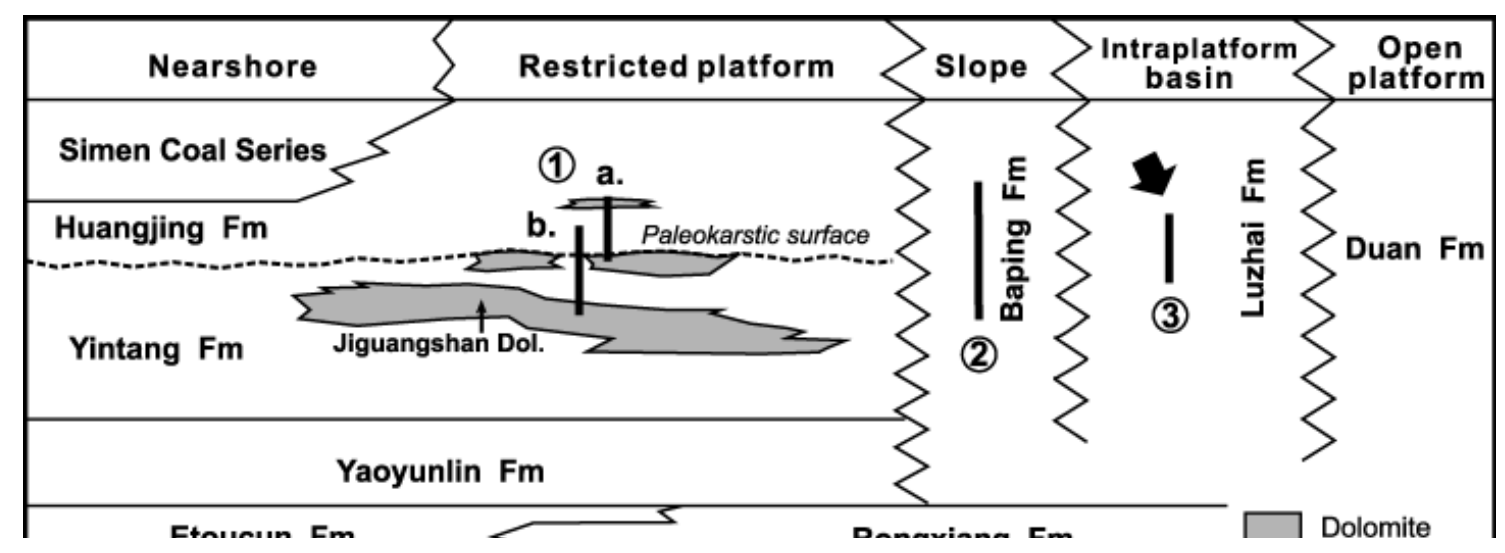


ence to E. simplex in the literature in some cases includes older representatives of the genus, that occur in strata of latest Tournaisian, not Viséan age. This is the case for E. ovalis Vdovenko, 1954 subsequently considered as a form of simplex (E. simplex form ovalis Vdovenko, 1964), which evolved in the Upper Tournaisian*.

Since 1995, very abundant material of Eoparastaffella has been collected in various localities across Eurasia. The best assemblages have been found in Western Ireland, Northern Iran and Southern China. In all regions, an evolutionary lineage has been recognized from the Upper Tournaisian (anchoralis zone) to a level high in the Lower Viséan (Cf4 $\delta$ biozone). This morphological evolution was first identified by Vdovenko (1964) in the Donbass. Although the specific composition of the Eoparastaffella population may vary between distant areas, an Upper Tournaisian group can easily be separated from a Lower Viséan group in each assemblage (Figure 3).

The Upper Tournaisian group is characterized by primitive specimens with a rounded peripheral outline of all whorls in axial view and a relatively low diameter/width ratio (morphotype 1 of Hance, 1997, Figure 3). The majority of these ancestral forms are only slightly or not umbilicate and are usually robust (thick granular wall, strong chomata). These forms include Eoparastaffella rotunda, E. fundata and primitive representatives of E. ovalis.

The Lower Viséan group is characterized by the appearance of more evolved specimens with a subangular periphery in the last whorl and higher diameter/width ratios (morphotype 2 of Hance, 1997, Figure 3). These younger forms have thinner and more microgranular walls and are clearly umbilicate. They also have a more rapid elevation of the last whorl than most Tournaisian forms and have more chambers per whorl. These new incoming forms include $E$. simplex minima and $E$. simplex typica together with evolved $E$. ovalis. The evolutionary link between these two groups is E. ovalis which displays a progressive morphological evolution across the TV boundary, leading to the appearance of the first true simplex in the Lower Viséan. The biostratigraphic criterion for the base of the Viséan proposed by the Working Group is therefore the first appearance of Eoparastaffella simplex in the lineage E. ovalis-E. simplex. This criterion has been formally approved by the Voting Members of the SCCS in 2002 (Work, 2002). It offers the advantage of keeping the base of the Viséan very close to its historical definition (Conil et al., 1969).

To overcome taxonomic problems and to make the definition of the base of the Viséan more objective, Hance and Muchez (1995) and Hance (1997) proposed a biometric approach. They use an e/r coefficient to calibrate the shape and elevation of the last whorl, $r$ being the radius of the largest circle which can be included in the last whorl above the umbilicus, and e the distance along the symmetry axis, between this circle and the periphery (Figure 3). In primitive specimens referred to as morphotype 1 , the circle superposes quite well on the periphery, giving a ratio close to 0 . Higher angularity of the last whorl and a general more rapid elevation of the last whorl in younger morphotype 2 is reflected by increasing e/r ratios which can range up to 0.9 (Figure 3). The basal Viséan is characterized by the appearance of forms with $\mathrm{e} / \mathrm{r} \geq 0.4-0.5$ while Tournaisian forms always have lower values (as low as 0 for some E. rotunda).

However this coefficient characterizes only one aspect of the morphological evolution of Eoparastaffella across the T-V boundary and has some limitations: 1) it cannot be measured directly on published plates and requires the use of scanned photographs and of drawing software; 2) there is some latitude in positioning the circle for ovoid primitive specimens with subparallel flanks leading to significantly different e/r values and; 3) evolved specimens with a strongly angular periphery but large width such as Eoparastaffella simplex form lata Vdovenko, 1971 and some representatives of Eoparastaffella simplex typica Vdovenko 1964 have comparatively low $\mathrm{e} / \mathrm{r}$.
E. simplex typica Vdovenko 1964

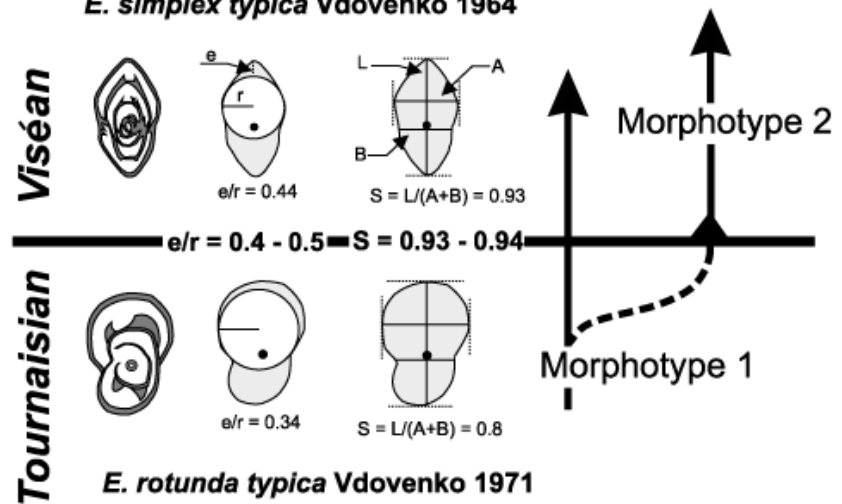
Figure 3 Eoparastaffella morphotypes and morphometric
coefficients across the $T / V$ boundary.

Point 2 can be resolved by positioning the circle with its diameter tangential to the base of the last but one whorl.

The sphericity coefficient (S) has been proposed to characterize the evolution of the general shape of the test by Devuyst et al. (2001) and Sevastopulo et al. (2002) (Figure 3). S is the ratio of the diameter of the test $(\mathrm{L})$ to the sum of the maximum width $(\mathrm{A})$ and the width tangential to the lower half of the proloculus (B) (Figure 3). In primitive forms $\mathrm{A}$ and $\mathrm{B}$ are very similar while in evolved representatives of the genus A is always much larger than B. Tournaisian forms are characterized by values below $0.93-0.94$ and as low as 0.73 in our data set. In the basal Viséan, forms with $S \geq 0.93-0.94$ appear (Figure 3 ) and the maximum value encountered for Eoparastaffella simplex in our data set is 1.2 . S is easy to measure even directly on published plates and leaves no room for interpretation.

A coefficient integrating the main morphological elements of Eoparastaffella is currently being tested. It should provide a simple tool for the non-specialist to discriminate the various species of the genus. Note that all coefficients require good axial sections.

\section{The Pengchong section}

\section{General setting}

The section is located in the small village of Pengchong, $15 \mathrm{~km}$ N/NE of the city of Liuzhou and about 2 hours drive from Guilin International Airport, at a latitude of N-24 $26^{\prime}$ ' and a longitude of E$109^{\circ} 27^{\prime}$ (Figure 1). The sequence is exposed in the bed of a stream flowing SW-NE in between cultivated areas in a small valley (Figures $4 \mathrm{c}-\mathrm{d}$ ).

Access from the city centre of Liuzhou takes about 40 minutes by car following the road to Luorong heading North and then NE outside the city alongside the railway to Guilin. Vehicles can be parked less than $300 \mathrm{~m}$ from the beginning of the exposure on top of a small hill above the village. A small path leads to a little basin in the stream which is used as a washing-place by the villagers and which corresponds to beds $45-55$ of the section.

The Pengchong section is situated in the South China Block, on the southern flank of a anticline with an axis oriented E/NE-W/SW and plunging to the W/SW. The northern flank of this anticline is faulted (reverse fault) and the whole structure has been affected by later minor transverse N/NE-S/SW and N/NW-S/SE faults (Figure 4a). The section exposes a $110 \mathrm{~m}$-thick dominantly carbonate sequence that straddles the T-V boundary and is contained within culm facies of the Luzhai Formation (Figure 2). In the present work, this carbonate sequence is considered as one unit informally called the Pengchong Member. In the Liuzhou Sheet $(1: 50,000)$ of the Guanoxi oenlooical man (Fioure $\Delta r$ ) this corresnonds to the middle 

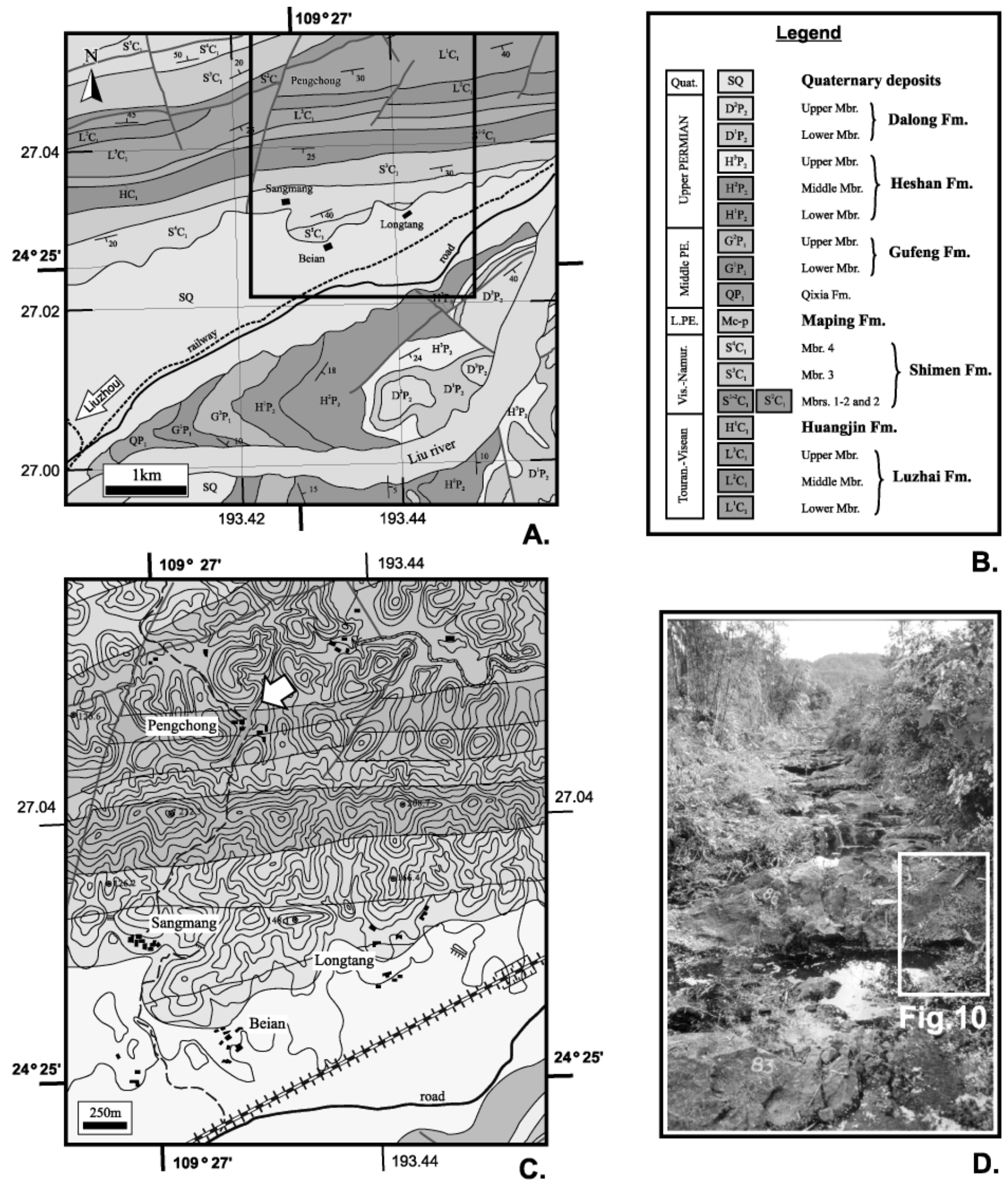

Figure 4 A. General geological setting of the Pengchong area (modified from the map of the Geological Survey of Guangxi).

B. Legend and sigles of A. and C. Mbr.- member, Fm.- formation, Tourna.- Tournaisian, Vis.- Viséan, Namur.- Namurian, L.- Lower, PE.-Permian, Quat.- Quaternary. C. Detailed geological and topographical map of the Pengchong area. The legend is the same as for A. but colours are paler for easier reading. The Pengchong section is arrowed. D. The Pengchong section viewed from the T/V boundary (base of bed 85). The position of Figure 10 is indicated. 
During the Mississippian, South China was located in a subequatorial position, just North of the palaeo-equator (Golonka et al., 1994; Scotese, 2001). Late Tournaisian and early Viséan sedimentation took place on a very wide carbonate platform dissected by a network of narrow and elongated intraplatform basins. The platform was bordered to the NW by the Yangzi Old Land and to the SE by the Zengcheng-Leiqiong Old Land (Figure 5; Wu and Chen, 1989). Nearshore mixed siliciclastic-carbonate rocks are restricted to the southern margin of the Yangzi Old Land. The intraplatform basins were fault-controlled (reactivated intracontinental basement faults) in the Devonian (Chen et al., 2001a; 2001b) and most likely also in the Lower Carboniferous, as their positions remain very similar. It is likely that they possessed notable breaks of slope. The Pengchong section is located in one of these basins.

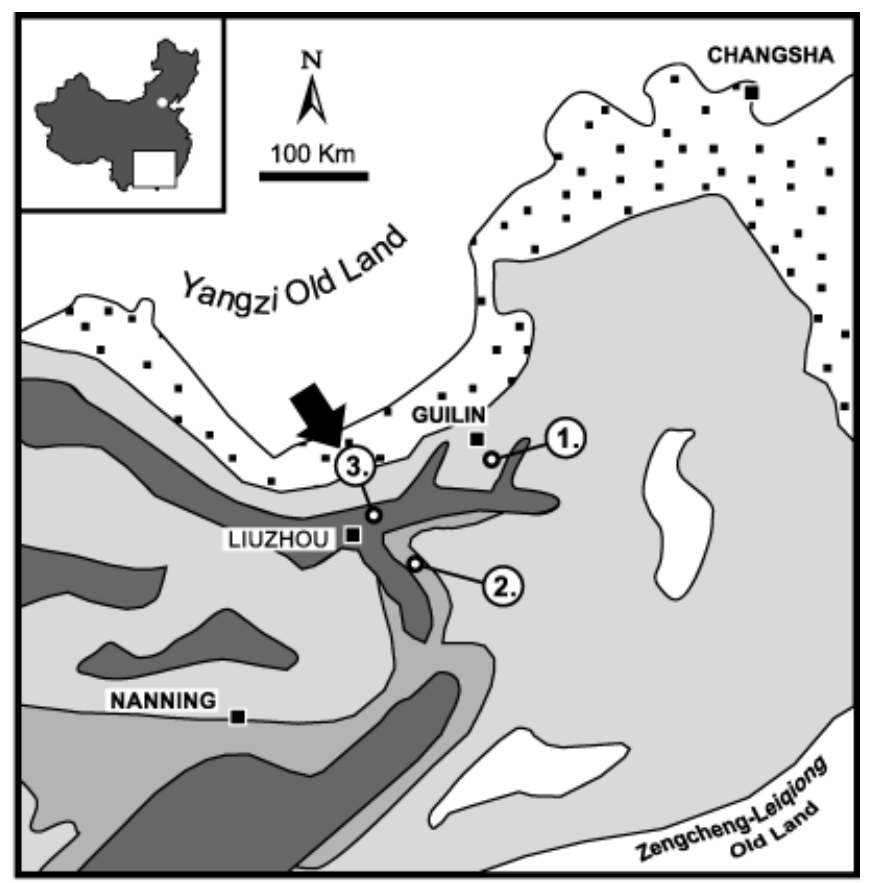

Figure 5 Palaeogeographical setting of the studied sections (after Wu and Chen, 1989). 1- Huaqiao Farm, 2- Yajiao, 3-Pengchong (arrowed).

\section{Sedimentology}

The Pengchong Member is composed of dark grey limestone beds of various thicknesses (mainly in the range $20-150 \mathrm{~cm}$ ) interbedded with subordinate thin- to medium-bedded ( $\triangle 10 \mathrm{~cm}$ but up to $60 \mathrm{~cm}$ locally) dark calcareous shales that become more abundant and thicker towards the top. The member is organized in decametre-thick parasequences, either thinning and shalier or conversely thickening and more limestone-rich upwards. These parasequences cannot be correlated with other nearby sections, neither on the platform nor with slope sections. Some isolated thick limestone beds occur in the upper part of the Lower member of the Luzhai Formation in otherwise culm facies but the base of the Pengchong Member is sharp and the lower part of the member does not contain interbedded culm facies. In contrast, the top of the member is transitional to the capping culm facies. The culm facies below and above the Pengchong Member is characterized by regularly alternating thin-bedded $(<10$ $\mathrm{cm})$ siliceous deposits and dark shales.

Outcrop conditions are not ideal to observe sedimentary structures but they seem very rare, except for horizontal laminations which are common in decimetre-thick beds and in the upper part of

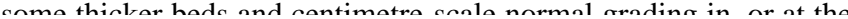

tions (HCS) occur locally (beds 95-100 and 204). The only trace fossils that have been observed are Chondrites sp. in bed 71 .

The dominant microfacies (Mf.1) in the limestones is fairly rounded bioclastic-lithoclastic packstone to grainstone with a shallow open-marine microfauna dominated by pelmatozoans, foraminifers and moravamminids and, to a lesser extend, by brachiopods and molluscs. Algae (mainly filamentous algae of the Girvanella type, red algae and Koninckopora but also rarer other dasyclads) and aoujgaliids are common. The degree of fragmentation, rounding, micritization and micrite coating is moderate to high. Cryptocrystalline grains are abundant and rounded micritized lithoclasts common to abundant. More or less micritized ooids are also common. There are variants of this microfacies according to the granulometry, with finer grained subtypes being very well- to wellsorted and coarser grained subtypes moderately-sorted to unsorted. A second less common microfacies (Mf.2) is medium-grained, moderately sorted, organic rich, compacted bioclastic packstone with the same open marine microfauna as Mf.1, but dominated by moravamminids and with common to abundant sponge spicules and rare radiolarians. This microfacies is most common in thin beds $(<15 \mathrm{~cm})$ or on the top of thicker beds. The third microfacies (Mf.3) present in the Pengchong Member is fine grained, very well sorted, laminated argillaceous organic rich packstone-wackstone to packstone dominated by sponge spicules, thin shells and delicate moravamminids. Small shallow open marine bioclasts (foraminifers, pelmatozoans, brachiopods etc.) and cryptocrystalline grains are present but never abundant. This microfacies is most commonly observed in thin beds $(<15 \mathrm{~cm})$ or rarely on top of thicker beds.

Most of the limestone beds are characterized by a bimodal size distribution of allochems with poor to moderate sorting. Better sorted and finer grained microfacies always occur in thinner beds but otherwise there is no general relationship between bed thickness and granulometry. Most of the limestones have a coarse silt to medium sand granulometry with scattered coarse sand to granule size allochems; a few beds reach very coarse sand grade with scattered allochems up to pebble size. Internally the thinner beds are ungraded or normally graded while the thicker ones are more complex, commonly displaying a coarser grained interval somewhere in their central part and in some cases at their base (either normal or reverse graded base).

The characteristics of the limestones of the Pengchong Member point towards mass flow deposits - modified grain flows or highdensity turbidites - reworking mature shallow open marine sediments from the nearby platform (Mf.1). This interpretation is consistent with the palaeogeographic setting of the area. The shale interbeds are interpreted as background sedimentation. Microfacies 2 and 3 are though to reflect the increasing contribution of deep slope sediments and allochems deposited from suspension in the mass flow deposits. It is difficult to estimate the depth of deposition but the unfossiliferous nature of the interbedded dark calcareous shales, the absence of autochtonous macrofauna and the scarcity of trace fossils suggest restricted conditions. The basin was not necessarily very deep as there is no indication of limestone dissolution and as HCS occur at some levels suggesting a water depth in the range of the storm wave-base zone. The depth of deposition on the platform was without doubt much shallower (a few tens of meters) as shown by the combined presence of heavy micritization, thick micrite coating (some algal), ooids and common algae including various types of dasyclads.

There is very little vertical change in the composition of the limestones in the Pengchong Member, except the increasing abundance of sponge spicules and radiolarians in the upper part. This change is accompanied by an increase of the shale interbeds (both in frequency and thickness), by a general increase of the proportion of thinner limestone beds, and by a replacement of the typical mass flow microfacies (Mf.1) by sediments deposited from suspension or 
active faults, the latter probably exercised a major control on the incidence of mass flow deposition.

\section{Biostratigraphy}

\section{Conodonts (Figure 6)}

The distribution of the conodonts in the Pengchong section is based on the study of 81 limestone samples, mostly of 1 to $2 \mathrm{~kg}$ in weight. Almost all samples yielded conodonts but rarely in abundance. Typically the number of platform elements was less than 10 per $\mathrm{kg}$.

In addition to the limestone samples, two calcareous shale testsamples (beds 71 and 85 ) have been processed for conodonts but they were barren.

The conodont faunas are dominated by the platforms of Gnathodus spp., and Polygnathus bischoffi, with rarer but still moderately abundant Mestognathus spp. The most notable features of the succession of faunas are: 1) The occurrence in bed 1 of Polygnathus bischoffi and Mestognathus sp., indicating that the section sampled begins at a level high in the Tournaisian; 2) the occurrence of Scaliognathus anchoralis europensis and Pseudopolygnathus triangulus pinnatus (both rare) in beds 34-37 and 62, respectively; 3) the similarity of Gnathodus spp. below and above bed 85 (proposed boundary, see below), with the exception of Gnathodus homopunctatus, which first occurs in bed 86; and 4) the first occurrence of Lochriea commutata, identified on the basis of its distinctive $\mathrm{M}$ element, in bed 150. The faunas, which will be described and illustrated in a future publication, are consistent with the sedimentological evidence, being mostly derived from a shelf setting. In terms of their biostratigraphy, they are closely comparable with faunas from outer shelf settings in western Europe. It is not clear whether the lowest occurrence of Mestognathus beckmanni is below or within the section. Specimens of Mestognathus from the lower beds are small and may either be juveniles of M. beckmanni or M. praebeckmanni.

\section{Foraminifers (Figure 7)}

The study of the foraminifer population of the Pengchong section is based on more than 200 thin sections. Foraminifers are abundant and well preserved in most of the limestones in the section. They are derived from shallow open marine environments on the platform top. There is commonly granulometric sorting and larger specimens are found in the coarser facies. Their absence in fine-grained sediment is not stratigraphically significant.

The first limestone beds ( -3 to 0 ) included in the lower culm member of the Luzhai Fm. already contain a rich and well diversified foraminifer association. It includes Eoparastaffella morphotype 1 (E. cf. rotunda, E. cf ovalis and E. ovalis) together with Brunsia, Tetrataxis, Pseudotaxis, Eoforschia, Pseudolituotubella, Condrustella, densily septate endothyrids (Bessiella and Florennella), Endospiroplectammina, Latiendothyranopsis, Granuliferella, Spinoendothyra, Laxoendothyra gr. laxa, and Planoendothyra.

Successive FAD's complete this association in beds 1 to 83 . The most significants are : Septabrunsiina spp. and Palaeospiroplectammina mellina (bed 1), E. rotunda, E. ovalis and Eoendothyranopsis (bed 4), Loeblichia gr. fragilis (bed 6), Globoendothyra and Plectogyranopsis (bed 13), Endothyranopsis (bed 21), cf. Mediocris (bed 24), Endothyra spp. (bed 28), Mediocris (bed 35), Paraendothyra cummingsi (bed 41), Eoparastaffella fundata (bed 67) and Vissarionovella sp. (bed 83).

In bed 85 the first Eoparastaffella simplex (form minima) appears and becomes common in bed 86 (Fig.8). More elongated and pointed ovalis with a higher elevation of the last whorl also appear at that level. The next significant FAD's are: Eostaffella gr. prisca (bed 117) (passing to much more evolved forms in the upper part of the section), Endospiroplectammina syszranica (bed 178), Pojarkovella

\section{Eoparastaffella}

The abundant material collected in the Pengchong section allows the recognition of distinct evolutionary branches. The most ancient representatives of the genus Eoparastaffella are the species $E$. rotunda and $E$. ovalis. The species $E$. rotunda appears first but data are lacking to identify the ancestor of the genus Eoparastaffella. The E. rotunda branch straddles the T-V boundary without significant morphological changes while the E. ovalis branch displays a gradual evolution in the Upper Tournaisian giving birth in the basal Viséan (just below the base of the $G$. homopunctatus zone) to evolved $E$. ovalis and the important E. simplex group (Figure 8). The E. fundata group is another disctinct branch that starts in the Uppermost Tournaisian above the E. rotunda and primitive E. ovalis (M. beckmanni Biozone) and persists without major changes until at least the upper $\mathrm{Cf} 4 \delta$ Biozone. It is also clear from our data that primitive Eostaffella evolve from Eoparastaffella in the Lower Viséan.

The envelope curves (maximum recorded values for a given level) of e/r and $\mathrm{S}$ for the Pengchong section are presented in Figure 9. The evolution of $E$. ovalis is responsible for the increase of both coefficients in the Upper Tournaisian. A distinct kick at the base of the Viséan corresponds to the entry of primitive Eoparastaffella simplex (form minima). In the Viséan both E. ovalis and E. simplex continue to evolve morphologically. The e/r and $\mathrm{S}$ indexes of the ancestral E. rotunda of bed -03 (not on Figure 9) are high as a result of their elongate morphology and absence of an umbilicus. This is resolved in the new coefficient currently being tested by integrating the angularity of the last whorl.

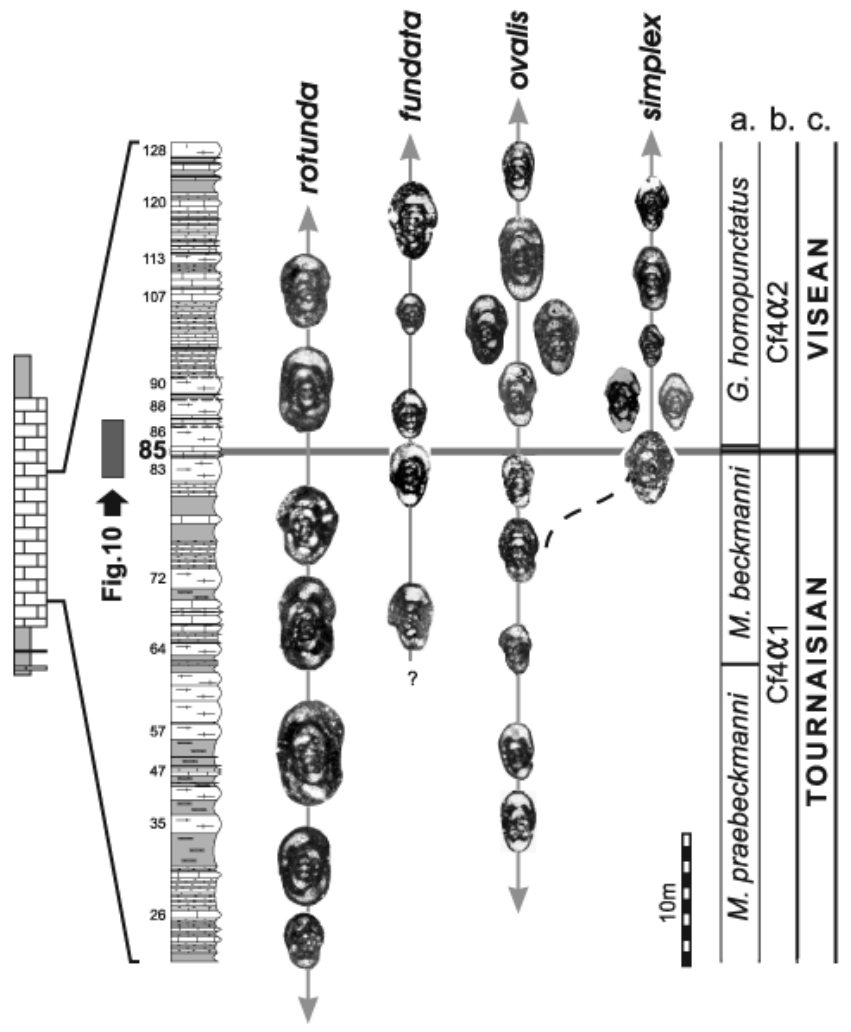

Figure 8 Evolution of Eoparastaffella across the T/V boundary in the Pengchong section. a.- conodont Biozones, $b$.- foraminifer biozones, c.- Belgian Stages, M.- Mestognathus, G.- Gnathodus.

\section{Macrofauna}

Macrofossils are very rare in the Pengchong section and only a few brachiopods and solitary corals have been observed. One Amygdalophvlum sp. (cf. sudeticum) (identification by E. Poty, Université de 


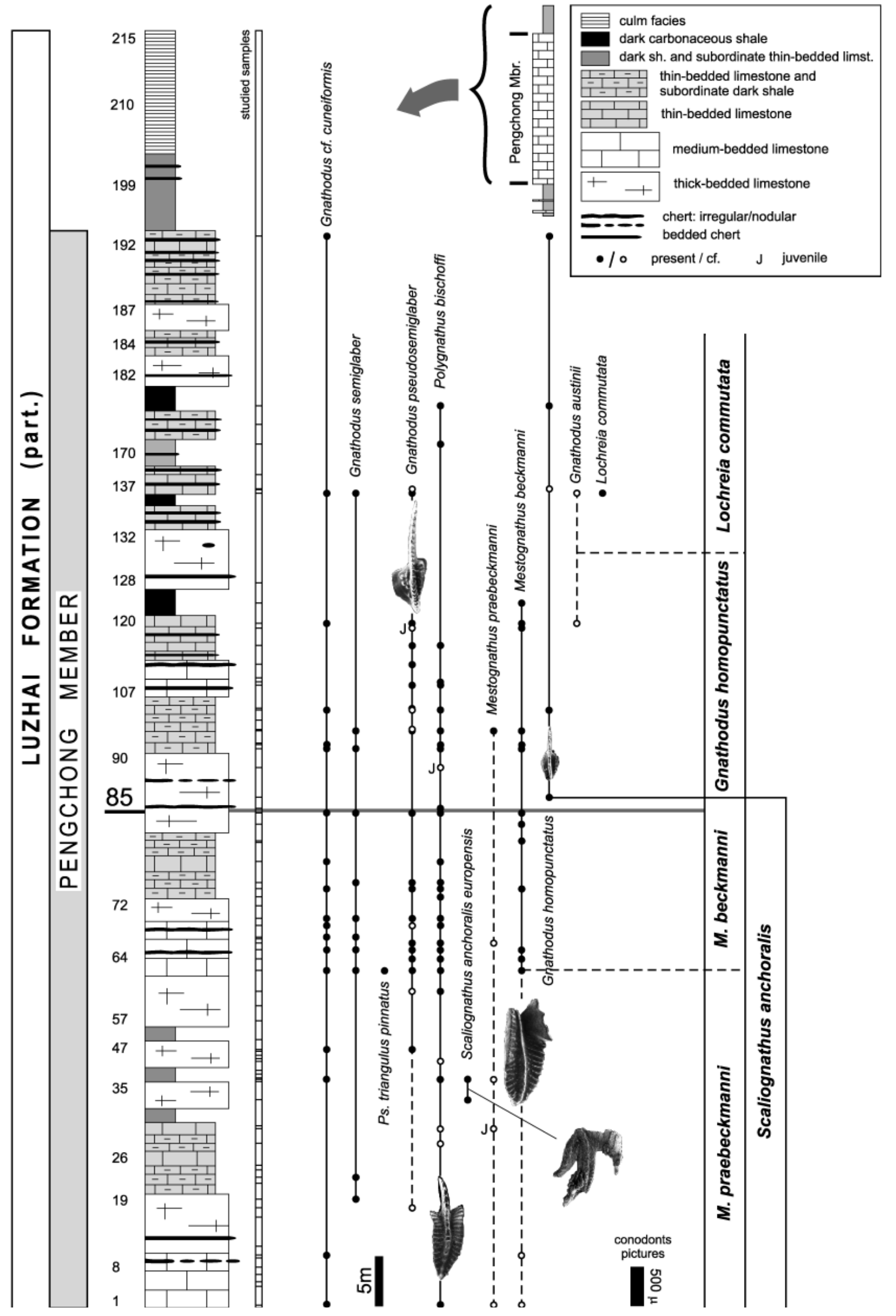




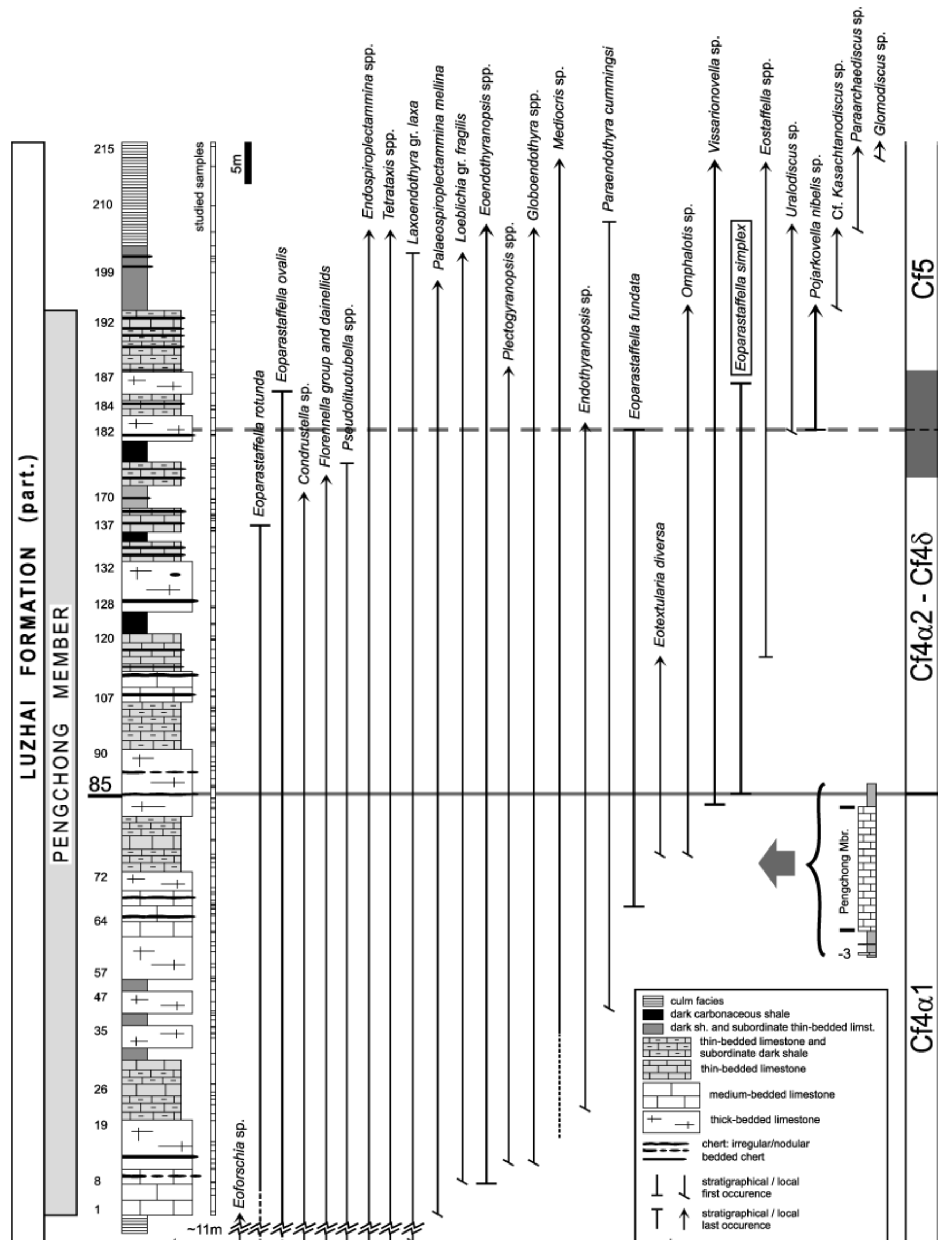


Hance et al., 2001) in the Uppermost Tournaisian but persisis into the Veséan.

However the nearby Yajiao section (slope facies; Figures 2, 5) contains ammonoids and trilobites and is correlated with the Pengchong section by foraminifers and conodonts.

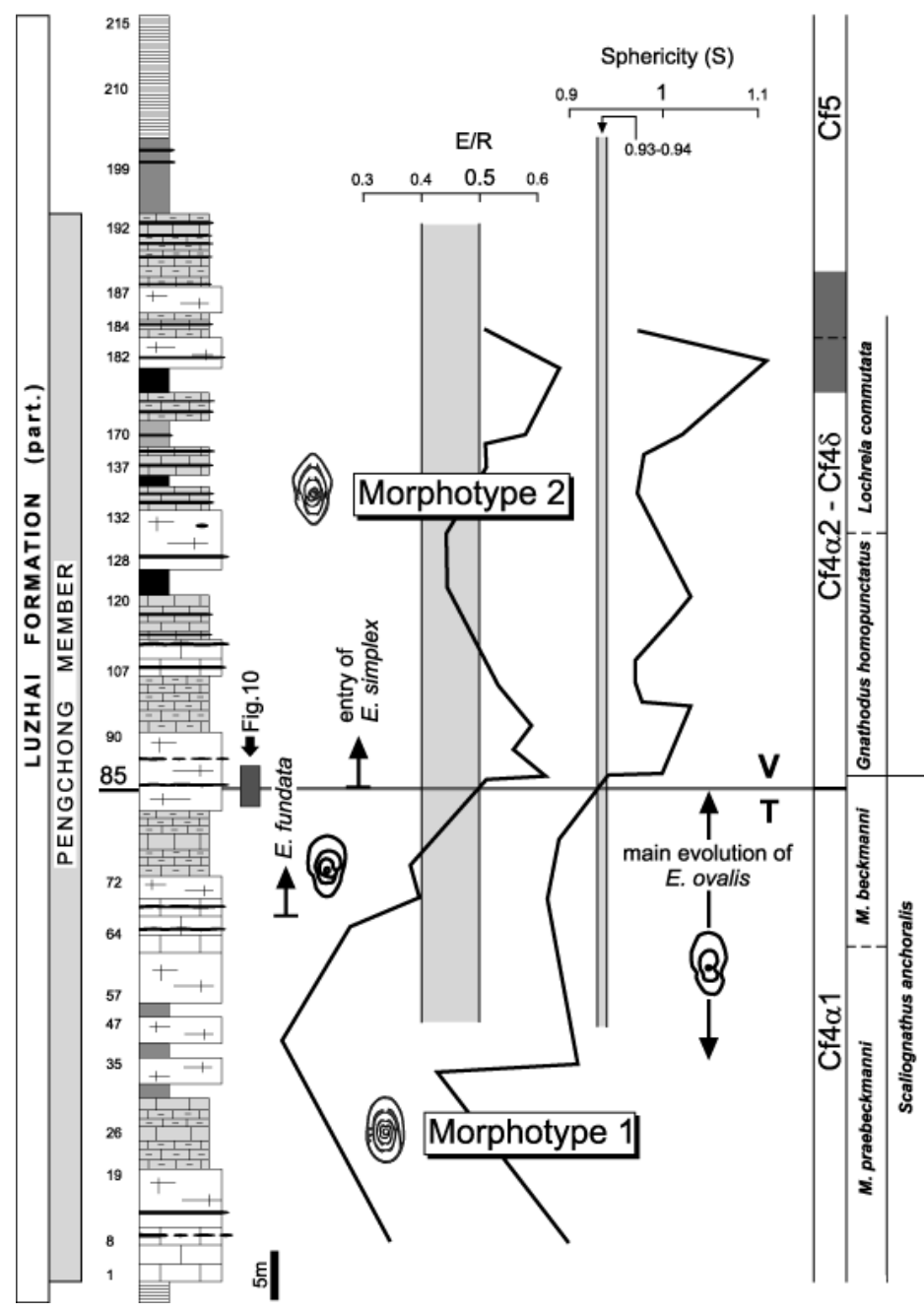

Figure 9 Evolution of the morphometric coefficients in the Pengchong section with foraminifer and conodont Biozones. E.- Eoparastaffella, M.- Mestognathus, T- Tournaisian, V-Viséan.

\section{Age interpretation and long distance correlations}

The Eoparastaffella Morphotype 1 foraminifer association from bed -03 to 84 is considered first. In this interval, the entries of Eoendothyranopsis (bed 4), of E. fundata (bed 67) and of Vissarionovella (bed 83, primitive specimens preceding typical $V$. tujmasensis) are thought to be stratigraphically significant and offer potential interesting elements for correlation. This association has also been recognized in the slope (Yajiao) and platform (Huaqiao farm) facies and described as association B (Hance et al., 1997). New material collected in these sections indicates older occurences of Eoparastaffella Morphotype 1, Loeblichia fragilis and Mediocris than reported in
Key conodont taxa associated with the Eoparastaffella Morphotype 1 association in Pengchong are Scaliognathus anchoralis europensis, Mestognathus praebeckmanni and Mestognathus beckmanni.

In Belgium, a rich and diversified Tournaisian foraminiferal association which predates the entry of Eoparastaffella Morphotype 1, Loeblichia gr. fragilis and Mediocris is present on the platform, in crinoidal limestones. These limestones correlate with the anchoralis conodont Zone (HST of sequence 4, Condroz Sedimentation area; Hance et al., 2001) and with the middle part of the Cf3 zone of Conil et al. (1977), defined in deeper environments in the central part of the Dinant Sedimentation area. It is also well documented from depths 3653-2950 m in the Saint-Ghislain borehole (Hainaut sedimentation area, Groessens et al., 1982). In Belgium, platform areas were emergent in the Uppermost Tournaisian and Eoparastaffella morphotype 1 is only present locally, in the rare and thin lowstand deposits of sequence 5 (Hance et al., 2001).

The Eoparastaffella Morphotype 1 association, preceding the entry of Viséan Eoparastaffella has also been recognized in Ireland (Dublin Basin - Rush Conglomerate, Western Ireland - Oughterard), in the Moravian Karst of the Czech Republic (Ondrackova, 2001) and in Northern Iran (Alborz range - Gaduk; Devuyst, in progress).

The FAD of Eoparastaffella simplex in bed 85 which is followed by that of the guide conodont Gnathodus homopunctatus in bed 86 marks the base of the Viséan (Figures 7, 10) and allows a good correlation with Belgium (Conil et al., 1989; Belka and Groessens, 1986) and other classical areas.

Above this level, the most significant change in the foraminiferal associations occurs in the interval 177-192 with the successive LAD's of: Pseudolituotubella (bed 177), E. simplex (bed 185), Florennella (bed 190), dainellids (bed 192); and the FAD's of Pojarkovella nibelis, cf. Klubonibelia and Uralodiscus (bed 182). This change correlates quite well with the Moliniacian-Livian transition in southern Belgium (Cf4 $\delta$ - Cf5 Zones; Conil et al., 1990) but is much better documented than in Belgium, where the uppermost Moliniacian and the lowermost Livian facies were unsuitable for the foraminifers and where an interzone actually separates the Cf4 and Cf5 Zones. Pojarkovella nibelis enters in Belgium in the lower part of the Livian and does not coexist with Moliniacian fauna. Reexamination of the Yajiao material confirms this coexistence. It has also been reported in the Mendips (SW England, Austin et al., 1973) and in the Visé sedimentation area in Belgium (Conil, in Kimpe et al., 1978, p. 58).

The delayed entry of the rare archaediscids recorded in Pengchong in the upper part of the section is probably related to the increased mixing of slope sediments at that level. Indeed early archaediscids did not thrive in shallow water environments (conditions prevailing in the source area of the reworked sediments of the Pengchong Member) and favoured somewhat deeper slope settings. This is confirmed by the abundance of the archaediscids in the Yajiao section (slope) below the first $P$. nibelis and by the occurrence of the conodont Lochriea commutata (marker for the base of the Arundian in the British Isles) well below the first archaediscids in Pengchong (bed 150).

\section{Does the Pengchong section fulfill requirements for a GSSP?}

\section{Geological requirements}

- The Pengchong section is continuously exposed over about $110 \mathrm{~m}$. It covers a rather large stratigraphic interval from the upper part of the S. anchoralis Biozone to the entry of the first Pojarkovella 


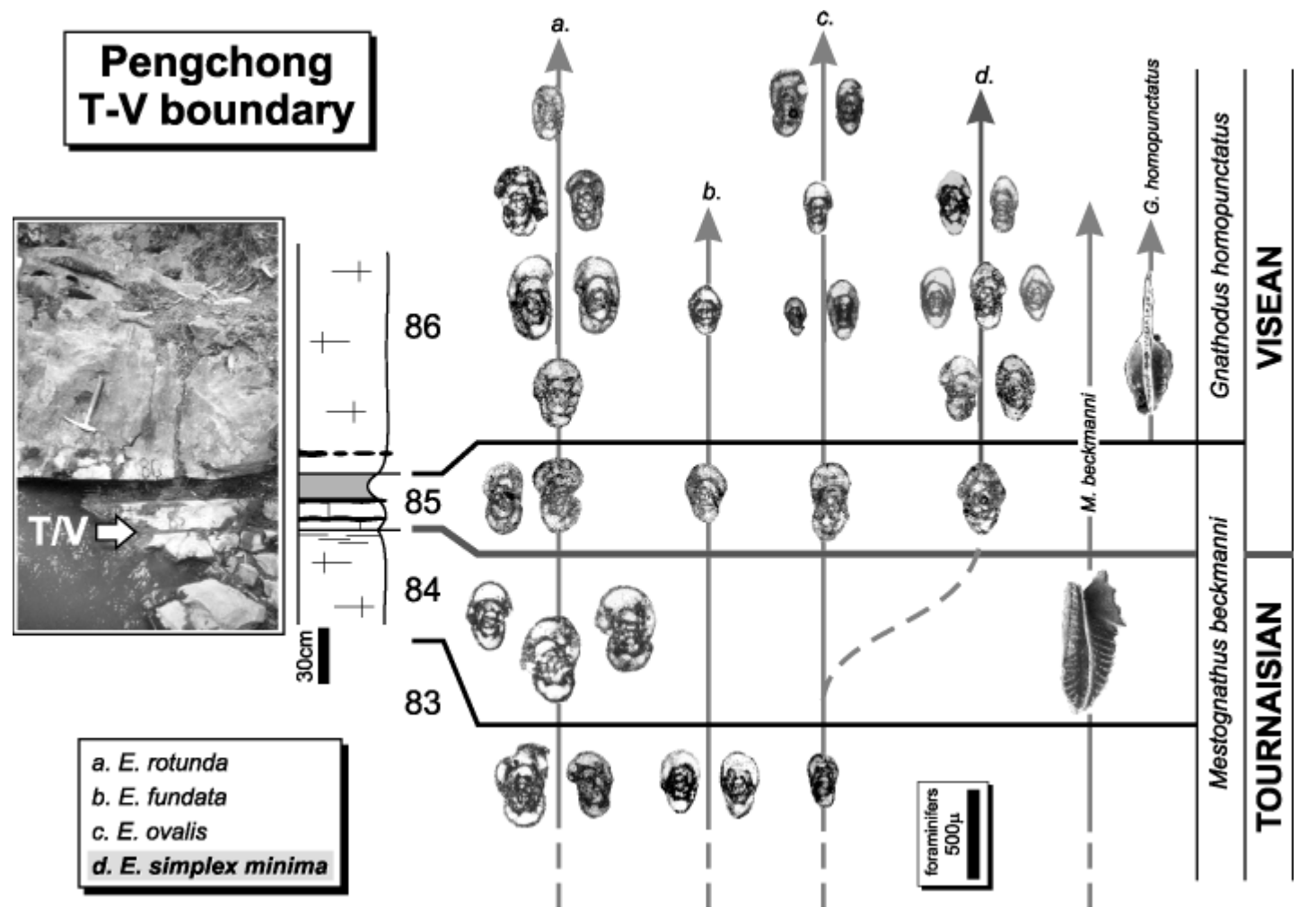

Figure 10 Detail of the T/V boundary (arrowed) in the Pengchong section with main Eoparastaffella species and the conodont guides. E.- Eoparastaffella, T- Tournaisian, V-Viséan.

- No important condensed interval or erosion surface were detected.

- Bedding is regular, being only affected locally by minor folds. No faults have been observed.

\section{Biostratigraphic requirements}

- Foraminifer are extremely abundant and diversified throughout and the early evolution of Eoparastaffella is very well documented. It is probably the best foraminifer record known to date in the $\mathrm{T}-\mathrm{V}$ transition and certainly the best record in one continuous section of the Eoparastaffella evolutionary lineage.

- Conodonts are not very abundant but important index taxa such as $S$. anchoralis europensis and G. homopunctatus are present. Moreover the nearby Yajiao section which has excellent conodont faunas, including common S. anchoralis europensis and Gnathodus homopunctatus, can be easily correlated with Pengchong.

- The Yajiao section has also yielded goniatites and trilobites that are currently being studied. Therefore there is a possibility to relate the ranges of these classical index fossils with the Eoparastaffella evolutionary sequence.

\section{Other methods}

The section will be investigated in the next phase of the project for chemostratigraphy, stable isotope stratigraphy (O and $\mathrm{C}$ ), magnetostratigraphy and magnetic susceptibility stratigraphy (MS).

Twenty calcareous shale levels have been collected between beds 25 and 114 for palynomorphs and the samples studied by G. Clayton (Trinity College Dublin, Ireland) but none proved productive.
The Chinese Academy of Geological Sciences will guarantee freedom of access to the section for research, and local authorities, in collaboration with the Geological Survey of Guangxi, will assure the permanent protection of the site.

\section{Acknowledgements}

We are most grateful to E. Groessens (Geological Survey of Belgium) who first measured the Pengchong section with Hance, Coen and Hou in 1993 and who identified part of the conodonts material, P. Muchez (Katholiek Universiteit Leuven) for his input in the understanding of the Guilin sedimentary basins in an early phase of the project, M. Duncan (Trinity College Dublin) for help with new collections of conodonts from Pengchong, G. Clayton (Trinity College Dublin) for the analysis of shale samples for palynomorphs, E. Poty (Université de Liège) for coral identifications, and especially the participants to the 1996 Liuzhou field trip for encouraging support and discussions. This research has been supported over the years by the Belgian National Funds for Scientific Research (FNRS), the Geological Survey of Belgium, the Chinese Academy of Geological Sciences, and the Ministry of Sciences and Technology of China (fund No. 2001DEA20020), we are most grateful to these organizations. M. Coen is a Research Associate of the FNRS and F.$X$. Devuyst also gratefully acknowledges the award of a research fellowship from the FNRS.

\section{References}

Austin, R., Conil, R., and Rhodes, F.H.T., 1973, Recognition of the Tournaisian-Viséan boundary in North America and Britain: Annales de la 
Brazhnikova, N.E., and Vdovenko, M.V., 1971, Foraminifera, in Aizenberg, D.E., ed., Atlas of the Tournaisian fauna in the Donetz Basin: Kiev, Naukova Dumka, pp. 21-64 and 124-212 (in Russian).

Brenckle, P.L., and Manger, W.L., eds, 1991, International Correlation and Division of the Carboniferous System: Courier Forschungsinstitut Senckenberg, v. 130, 350 p.

Chen, D., Tucker, M.E., Jiang, M., and Zhu, J., 2001a, Long-distance correlation between tectonic-controlled, isolated carbonate platforms by cyclostratigraphy and sequence stratigraphy in the Devonian of South China: Sedimentology, v. 48, pp. 57-78

Chen, D., Tucker, M.E., Zhu, J., and Jiang, M., 2001b, Carbonate sedimentation in a starved pull-apart basin, Middle to Late Devonian, southern Guilin, South China: Basin Research, v.13, pp. 141-167.

Conil, R., Austin, R. L., Lys, M., and Rhodes, F. H. T., 1969, La limite des étages Tournaisien et Viséen au stratotype de l'assise de Dinant: Bulletin de la Société belge de Géologie, v. 77, pp. 39-67.

Conil, R., Groessens, E., and Pirlet, H., 1977, Nouvelle charte stratigraphique du Dinantien type de la Belgique: Annales de la Société géologique du Nord, v. 96, pp. 363-371.

Conil, R., Groessens, E., Laloux M., and Poty E., 1989, La limite Tournaisien-Viséen dans la région-type: Annales de la Société géologique de Belgique, v. 112, pp. 177-189.

Conil, R, Groessens, E, Laloux, M, Poty, E, and Tourneur, F, 1990, Carboniferous guide foraminifers, corals and conodonts in the Franco-Belgian and Campine Basins: Courier Forschungsinstitut Senckenberg, v. 130, pp. 15-30.

Devuyst, F.X., Hou, H.F., Coen, M., Hance, L., Sevastopulo, G.D., Tian, F., and Wu, X.H., 2001, The Pengchong section (South China, Guangxi Autonomous Region), a GSSP candidate for the base of the Viséan (abs.): Subcommission on Carboniferous Stratigraphy Field Trip and General Meeting, St. Louis, USA, 2001.

Dumont, A., 1856, Carte géologique de la Belgique.

Dupont, E., 1861, Note sur les gîtes de fossiles du calcaire des bandes carbonifères de Florennes et de Dinant: Bulletin de l'Académie de Belgique, 2e série, t. 12, 293p.

Dupont, E., 1883, Explication de la feuille de Dinant: Carte géologique de la Belgique

George, T.N., and Wagner, R.H. 1969, Report of the International Union of Geological Sciences Subcommission on Carboniferous Stratigraphy: VIe Congrìs Int. Strat. Géol. Carbonifère, Sheffield, 1967, Compte Rendu, v.1, pp. XLII-XLV.

Golonka, J., Ross, M.I., and Scotese, C.R., 1994, Phanerozoic paleogeographic and paleoclimatic modeling maps: Pangea: Global Environments and Resources, Canadian Society of Petroleum Geologists, Memoir no. 17 , pp. $1-47$

Gosselet, J., 1860, Observations sur les terrains primaires de la Belgique et du Nord de la France: Bulletin de la Société géologique de France, 2e série, t. 18.

Groessens, E., and Noël, B., 1977, Etude litho- et biostratigraphique du Rocher du Bastion et du Rocher Bayard à Dinant: Symposium Namur 1974, Publication no. 15, pp. 1-17

Groessens, E., Conil, R., and Hennebert, M., 1982, Le Dinantien du sondage de Saint-Ghislain. Stratigraphie et Paléontologie: Mémoires pour servir à l'explication des cartes géologiques et minières de la Belgique, no. 22 (1979): $137 \mathrm{p}$.

Hance, L., 1997, Eoparastaffella, its evolutionary pattern and biostratigraphic potential: Cushman Foundation for Foraminiferal Research, Special Publication no. 36 , pp. 59-62.

Hance, L., and Muchez, P., 1995, Study of the Tournaisian-Viséan transitional strata in South China (Guangxi) (abs.): XIII International Congress on Carboniferous-Permian, Kraków, Poland, 1995, pp. 51.

Hance, L., Hou H., Muchez, P., Coen, M., Groessens, E., Wu X., and Xu S., 1996, Field meeting on the Tournaisian-Viséan transition in South China: IUGS Subcommission on Carboniferous Stratigraphy, Working Group on the Tournaisian-Visían Boundary, Guidebook, $51 \mathrm{p}$.

Hance, L., Muchez, P., Hou, H.F., and Wu, X., 1997, Biostratigraphy, sedimentology and sequence stratigraphy of the Tournaisian-Viséan transitional strata in South China (Guangxi): Geological Journal, v. 32, pp. 337-357.
Hance, L., Poty, E., and Devuyst, F.X., 2001, Stratigraphie séquentielle du Dinantien type (Belgique) et corrélation avec le Nord de la France (Boulonnais, Avesnois): Bulletin de la Société géologique de France, t. 172, no. 4, pp. 411-426.

Kimpe, W.F.M., Bless, M.J.M., Bouckaert, J., Conil, R., Groessens, E., Meessen, J.P.M.T., Poty, E., Streel, M., Thorez, J., and Vanguestaine, M., 1978, Paleozoic deposits east of the Brabant Massif in Belgium and the Netherlands: Mededelingen Rijks Geologische Dienst, v. 30, no.2, pp. 37-103.

Lees, A., 1997, Biostratigraphy, sedimentology and palaeobathymetry of Waulsortian buildups and peri-Waulsortian rocks during late Tournaisian regression, Dinant area, Belgium: Geological Journal, v. 32, pp. 1-36.

Lipina, O.A., 1973, Zonal stratigraphy and paleobiogeography of the Tournaisian based on foraminifera: Vopr. Mikropaleont. Moscow, v. 16, pp. 3-34 (in Russian).

Ondrackova, L., 2001, Tournaisian-Viséan boundary in Mokra near Brno (Czech Republic): Newsletter Carbonif. Strat., v. 19, pp.24-26.

SCCS, 1969, General discussion of Subcommission on Carboniferous Stratigraphy: VIe Congrès Int. Strat. Géol. Carbonifère, Sheffield, 1967, Compte Rendu, v. 1, pp. 185-189.

Scotese, C.R., 2001, Atlas of Earth History, Volume 1, Paleogeography, Paleomap Project: Arlington, Texas, 52p.

Sevastopulo, G., 1993, Report on Project Group 2: a mid "Lower Carboniferous" boundary: Newsletter Carbonif. Strat., v. 11, pp. 7-8.

Sevastopulo, G. Devuyst, F.X., Hance, L., Hou, H.F., Coen, M., Clayton, G., Tian, S., and Wu, X.H., 2002, Progress report of the Working Group to establish a boundary close to the existing Tournaisian-Viséan boundary within the Lower Carboniferous: Newsletter Carbonif. Strat., v. 20, pp. $6-7$.

Vdovenko, M.,V., 1954, New species of Foraminifers from the Lower Viséan of the Donets Basin: Kiev Univ. Schevshenko Nauk Zapiski, v. 13, no. 4, pp. 63-76 (in Russian).

Vdovenko, M.,V., 1964, Evolution of the Eoparastaffella-Pseudoendothyra: Acad. Sc. Ukraine SSR, Strat. Paleont., v. 48, pp. 16-30 (in Russian).

Vdovenko, M.V., 1971, New species and forms of the genus Eoparastaffella: Paleontologicheskii Sbornik, v. 7, no. 2, pp. 6-12 (in Russian)

Work, D.M., 2002, Secretary / Editor's Report 2001-2002: Newsletter Carbonif. Strat., v.20, pp.3.

Wu, X., and Chen, W., 1989, Studies on lithic facies and palaeogeography of Carboniferous in South China (Middle and Upper Yangtze region): XIe Congrès Int. Strat. Géol. Carbonifère, Beijing, 1987, Compte Rendu, v.4, pp. 127-134.

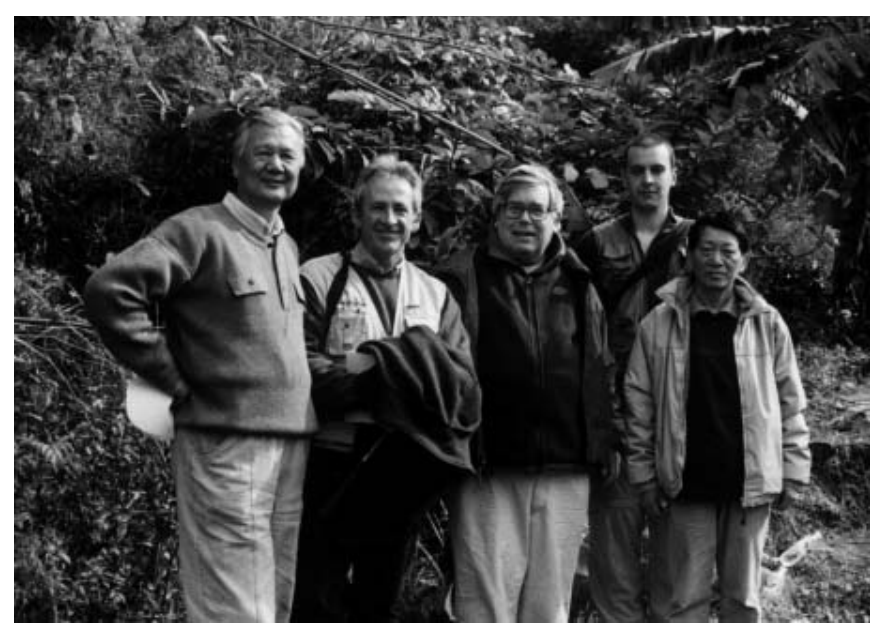

Some of the authors in the fieldwork, from right to left: Xianghe Wu, François-Xavier Devuyst, George Sevastopulo, Luc Hance, and Hongfei Hou. 